I. О. Іншакова, А. С. Іншаков

\title{
КОЛЬОРОНОМЕНИ НА ПОЗНАЧЕННЯ ГЕОГРАФІЧНИХ ТА ТОПОГРАФІЧНИХ НАЙМЕНУВАНЬ У ПАМ'ЯТКАХ СЕРЕДНЬОУКРАЇНСЬКОЇ ТА НОВОУКРАЇНСЬКОЇ МОВИ
}

Іншакова I. О., Іншаков А. Є. Кольорономени на позначення географічних та топографічних найменувань у пам'ятках середньоукраїнської та новоукраїнської мови.

Вивчення лексичної системи в іiі історичному розвитку неможливе без дослідження історії та особливостей розвитку окремих тематичних груп, зокрема кольорономенів. У статті проаналізовані кольоронайменування на позначення географічних та топографічних назв у пам'ятках середньоукраїнської та новоукраїнської мови.

Ключові слова: кольороназва, дериват, тематична група, номен, похідні, географічні, топографічні назви.

Иншакова И. А., Иншаков А. Е. Цветономены для обозначения географических и топографических наименований в памятниках среднеукраинского и новоукраинского языка.

Изучение лексической системы в ее историческом развитии невозможно без исследования истории и особенностей развития отдельных тематических групп, в частности цветономенов. В статье проанализированы цветонаименования для обозначения географических и топографических названий в памятках среднеукраинского и новоукраинского языка.

Ключевые слова: цветообозначение, дериват, тематическая группа, номен, производные, географические, топографические названия.

Inshakova I. O., Inshakov A. Y. Colornames for denotation of the geographical and topographical names in monuments middling Ukrainian and newly Ukrainian language.

Linguists study the history of color names, their etymology, the process of forming separate groups and their composition at different stages of language development, determine the correlation of each name of the color with the subject-standard. Usually, the analysis of the function of the coloroleks is given in the synchronous aspect. However, the diachronic study of color names is important for the process of formation and functioning of the relevant thematic group, the identification of the regularities of the formation of the historical lexicology of the Ukrainian language in general.

A characteristic feature of the monuments of the Middle Ukrainian period is the wide use of color names in the geographical names. Derivatives with a nominal white and its derivatives in geographical names can be combined into separate thematic groups: the names of cities and towns, villages, seas, rivers, tracts. Often, monuments are composed of names of cities with the use of the colored image. There are also separate titles of states. Among the areas of use of black nominae in the Middle Ukrainian language are often used geographical, toponymic names, which are grouped into separate thematic groups (names of cities, countries, toponymic names, names of villages, names of rivers, lakes, seas). A

(ㄱ.І. Іншакова, А. Є. Іншаков, 2017. 
number of new titles show the performance of the color rendering black. For the transfer of red color in the analyzed thematic group used names with ancient roots. The analyzed material confirms the widespread use of collo-Aleksiki in geographical and topographical names during the period under review. Some of the names have occurred in the previous period. The most productive in the worked out thematic group were white, black colors. A wide range of lexemes with different roots for the red color has been revealed. Less productive in the analyzed thematic group were blue, yellow, gray, green.

Key words: colornames, derivate, thematic group, nomen, derivatives, geographical, topographical names.

Різні аспекти становлення, розвитку окремих тематичних груп лексики розглядали у своїх дослідженнях С. Бібла, Г. Войтів, О. Зеленська, Г. Миронова, І. Сокіл, П. Чучка, С. Яценко та ін. Історичний аспект вивчення кольоролексем актуалізований у роботах Н. Бахіліної, О. Іссерлін, М. Чікало, Ю. Норманської, І. Садикової, В. Горобця, Л. Ткач, Р. Алімпієвої, Г. Герне, А. Заремби, П. Хілла, Н. Пелевіної, Л. Грановської, М. Суровцевої та ін. Мовознавці досліджують історію кольороназв, їхню етимологію, процес формування окремих груп та їх склад на різних етапах розвитку мови, визначають співвіднесеність кожного найменування кольору 3 предметом-еталоном.

Зазвичай аналіз функціонування кольоролексики подано в синхронному аспекті. Проте діахронічне дослідження кольоронайменувань $\epsilon$ важливим для процесу становлення та функціонування відповідної тематичної групи, виявлення закономірностей формування історичної лексикології української мови загалом. Це й зумовило вибір теми статті та іï актуальність.

Характерною рисою пам'яток середньоукраїнського періоду $є$ широке вживання кольоронайменувань у складі географічних назв. Деякі номени траплялися ще попереднього періоду: місто Б $\underline{\mathbf{k} л а}$ Вежа (ЛГ 259); а кто идєть...у б блльи городъ поль рубєль сєрєбра (1408 ССУМ I 95); or Б 103), Б клоградъ (1480 ССУМ I 148); посла ихъ подъ Б қлагородъ (1516 ЛГ 49); ...бо войска иесарскіе, стоячи у Білграді, свояволю великую чинити почали... (1691 ЛСам 152). У джерелах нової української мови незначна кількість подібних утворень: Білагород (Кв.-Осн. I 37) «назва

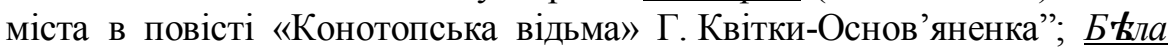
Церква (РД 117; ЗЮР І 60); зъ Білоі Русі (ЗЮР І 231).

Деривати 3 номеном білий та його похідними в географічних

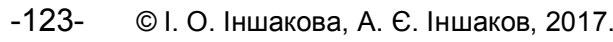


назвах можна об’єднати в окремі тематичні групи:

- назви міст та містечок. Особливістю цієї групи є поодинокі суфіксальні утворення, переважають складні деривати: Білобереззя (1595 СелР 407); Б Белозерье (ВУР I 551); Білогір'я (Ляхівці) (XVII 30-і рр. ЛОстр 134); Белоусовка, Белозер (1648/1654 ВУР III 617); Білобожниия (1645 СелР 478); Белов Полє, Белокоровичи, Бєлокоровсков (XVI ВолГр 232) тощо;

- назви сіл: село в Молдавському князівстві Б қлал Кръниця:

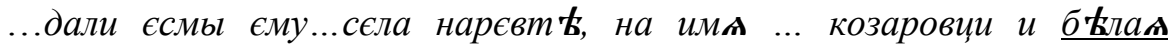
кръницл (1436 ССУМ I 148) та його варіант Білокриниччя (1594 СелР 405); Б Б九лыи бєрьги (село в Подільській землі): ...на имы тоє сьло...луку ниже бъльхъ берьговъ (1445 ССУМ I 149); Біличі (1506 ГВК 843); Білосток (1579 СелР 375); Білозорка (1583 там само 380); Білка (1588 там само 385); Білин (1601 там само 425); Білівиі (1603 там само 428); Білопілля, Білополь (1605 там само 430); Біла Криниия (1609

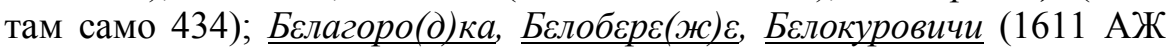
375); Білий Потік (1622 СелР 448); Білки (1625 там само 452); Белозеро (ВУР I 551); Біла Воля (1630 СелР 457); Біле Озеро (1638 там само 281); Білогориа (Білогоща) (1636 там само 258);

- назви повітів, слобод, хуторів, замків, сотень: Белевский (ВУР I 551); Белгородський (1634 СелР 462); Беломестная (ВУР I 551);

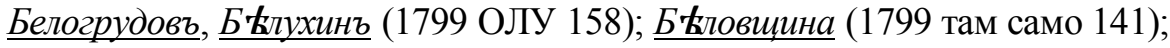
Беловежской (1799 там само 153); Белиловски(u) (XVII ДМВН 269); Белочсрковскій замок (ЛГ 259); Білогородська, Білоуська (УУГ 871, 946);

- назви морів, річок: Белое (Мраморное) море (1648-1654 ВУР III 617); того ж року на Білом мору визера турецкого громили (1685 ЛСам 141); Біле море, Гниле море (Сиваш): а запорожское войско ходили под Перекоп и там над Білим морем вежу виняли... (1694 там само 154); на бъло(м) потоиі (1414 ССУМ I 149); Біла Калитва, Біла Плата, Білий Колодязь (1641 ВУР I 551); Бельле берега (перевіз на річці Сеймі) (1648-1654 ВУР III 617); Білоус (УУГ 954); Білиця - права притока Івоті, ліва притока Десни (басейн Дніпра) (УУГ 954) (омонім до однойменного села Білиця Ямпільського району Сумської області). Нова українська мова успадкувала незначну кількість лексем із попереднього періоду (Біла, Білоус $)$, низка новотворів свідчить про збільшення назв цієї мікрогрупи: Біла Лугань, Біла Тиса, Білашка, Біленька, Білий Черемош, Білий Яр, Білозерка, Білосарайська, Білосток, Білоч (КРУ 157); на білим потоком (Романів 15); біловод (Чаб I 86) «озеро або річка (ㄱ.І.О.Іншакова, А. Є. Іншаков, 2017. 
3 чистою, прозорою, білуватою водою і піщаним дном»;

- назви урочищ: ... а шть Пер оунова Доуба до Б (1301 ГВК 681); Белая гора (назва урочища у Волинській землі): грань...зь леса...подъ Белую гору (1322 ССУМ I 149); яко сє вышь списало, у урочища Бєло(2)(o)... (1639 КПС 195); при р $\mathbf{k} к \mathbf{t}$ Ипут $\mathbf{t}$

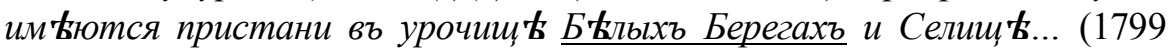
ОЛУ 124); інші топоніми: Белая гора (1322 П 21); Бълошевы с ъножати (1349 там само 27); Белєва (Белова) гора (XVI ВолГр 232) та ін.

Часто функціонують у пам'ятках складені назви міст із уживанням розглядуваного кольоратива: жолніре, видячи тоє, стали обозом за Білою Церквою...(XVII 30-і рр. ЛьвЛ 117); Бр 8ховсикій с калмиками ходиль по(д) Б 213) і похідні: Белоче(р)ковски(и) кгрунт; Белоче(р)ковская ствна; Белоче(р)ковская дорога; Бвлоче(р)ковски(и) гостинси (1584-1644 КПС 312); Бълій Камєнь (ЛГ 259). Цю ж назву мали й інші топонімічні об'єкти, зокрема, озеро Білий Камінь (1292 ГВК 578); урочищъ у Белого Камєна у могиль (1597 КПС 89), на позначення якоїсь певної місцини - білий камінь (1650 ГВК 1009).

Iз XVII ст. у джерелах розглядуваного періоду активно

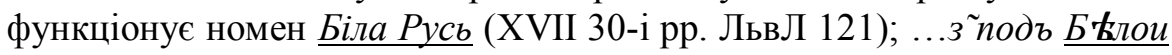
Руссь вєликіи государъ... (1654 ЛГ 154); Білая Русь (1654 ЛСам 69); (XVIII ГВК 1109).

Трапляються й поодинокі назви держав: давали выходь Б $\underline{\mathbf{k} л о и ̆ ~}$

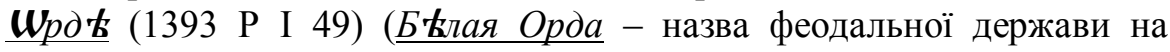
території Казахстану); Белилоvка (1635 АЖ 141).

Серед сфер використання номена чорний у середньоукраїнській мові часто вживаними є географічні, топонімічні назви. Їх можна об’єднати в окремі тематичні групи:

- назви міст, країн: Чєрновци, Чєрновьщ̧и (назва міста на Буковині): а што было дати єму у чєрновьци, то имєть дати у хотини (1408 ССУМ II 537); Чернь (ВУР I 563); (1462 КП 201); Черниговъ (там само 231); ...а поплатовъ платити и иных никоторыхъ пошлин в Чорнобыли не велели (1450 там само 547); Чврнсхор (1635 АЖ 165); Чорна Русь (ЗЮР II 264) тощо;

- топонімічні назви: Лесокъ Чорный (1322 П 21); под Чорныи Лєсокъ йшъ... (1322 ГВК 693); Пъсокъ Чорный (1393 П 113); вылиоль

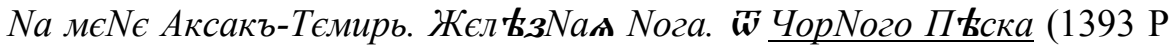


48); чорний $n$ kсокъ (староукраїнський переклад тюркської назви місцевості у володіннях Тамерлана) Каракуми (ССУМ II 548); ...u поперєк пола къ ЧорNомоу лtсоу. $\kappa$ потокоу. $к$ лоцжешєв 83); Чєрниковъ прикметник Чєрниково дворищє (1463 ССУМ II 537) «назва земельної ділянки у Волинській землі»; Черничин (ГВК 1261) «болото»; Чернече (там само) «урочище»; аже ємог побраль. пан

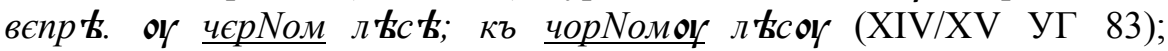
Чернеховская Дубрава (ВУР І 562); Черный шлях (ВУР I 563); Чернечий Яр, Чернев, Чернеча Слобода, Чернижів, Чернишівка, Черноводський, Чернолушина, Чернуської Пустиньки (XVIII ОЛУ 318); Чорнобабки (там само 319) та ін. Нова українська мова фіксує назви середньокраїнського періоду: Чорний илях (СМШ II 414); на високій чорногор бу буйі в могилу (РД 15); в чорн ъй гор п положите (там само 10); Чернече поле (Теребовельщина 179);

- назви сіл, хуторів та слобід: Чернєхов (1435 ССУМ II 537); Черниковцы (1463 там само); Владъ чорныли (назва села в Молдавському князівстві) (1490 там само 180); Черників, Чернів (1589 СелР 387); Чорнятин (1593 там само 399); Чعрниговци, Чврнчичи (XVI ВолГр 234); Чорногородка (УУГ 955) «село Макарівського району Київської області»; Чернин (там само 1041); Чع(р)ня(в)ки (село) (1611 АЖ 332); Ча(р)нобы(л) село (там само 378); Черниця (1635 СелР 464); Чернігівиі (1646 там само 480); Чернявка, Чорна (XVII СелP 479, 393); Чернече (1794 ГВК 1106); Чернетщина (1799 ОЛУ 143); Чернетичи (там само 137); Черняховка (там само 136); Чорнухи (ЛГ 272); Чернышъ (1799-1801 ОЛУ 131); Чернечая Слобода (там само 153); Чернобаи (1799 там само 167); синонімічні назви Черноглазовка (1799 ОЛУ 179) та Чернооковъ (там само 143) тощо;

- найменування річок, озер, морів: a топерь тоцрии перєст оупили чръмноє море занже вздль кар ог (1484-1486 ССУМ II 550); Чорнор оцй (1492 там само 547) «назва річки у Волинській землі»; Черное Жеребье (Черный Жеребеи) (ВУР I 562); Чорне море

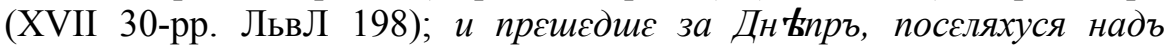
Чع(р)нимъ моремъ... (1739 ЛГ 40). У сучасній українській мові 3 попереднього періоду функціонують окремі назви: Чорне море (ЗЮР II 201; $\quad$ РД 118; $\quad$ Гр IV 470); $\quad$ Чорноморія $\quad$ (СМШ II 414) «узбережжя Чорного моря». Низка нових найменувань свідчить про 
продуктивність кольорономена чорний: Тиса Чорна (КРУ 187); Черемош Чорний, Чернеча, Черня, Чорна Вода, Чорна Долина, Чорний потік, Чорний Ташлик, Чорнова, Чорноводка, Чорногузка, Чорнява, Чорнявка (там само 190).

Для передачі червоного кольору в аналізованій тематичній групі використовувалися номени із давніми коренями (індоєвропейський руд<*rudh-; спільнослов'янські черв-<*červ-; багр-<*bagъr- та інші).

Серед похідних від кольороназви рудий у пам'ятках трапляються

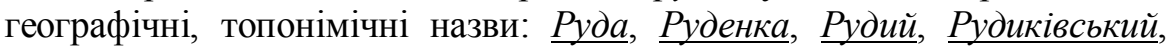
Pудівка, Pудка, Рудня, Pудницьке (XVIII ОЛУ 313); селища: $\underline{P y д к а, ~}$ Рудки, Рудня (УУГ 1040); Рудка (1630 ІФ 151); село Рудники (1584-1644 КПС 320); Pуда (1584-1644 КПС 320) «струмок у Київському повіті»; струмки: $\underline{P y \partial \kappa a, ~ P у д а в и н а ~(1584-1644 ~ К П С ~ 320) ; ~} \underline{P y \partial \kappa a ~-~ р і ч к а ~ в ~}$ Чернігівській області (1677 УУГ 184); Рудяки (СМШ II 217) «назва села на Київщині»; річка $\underline{P д а ~ К р и н и щ я ; ~ м а л а ~ р і ч к а ~ Т е р е б о в е л ь щ и н и: ~ Г н и л а ~}$ Pудка (від болотняного річища, бо рудка, рудавина «болото» первісно ще й червоного кольору); потік Гнила Рудка (Теребовельщина 171, 178);

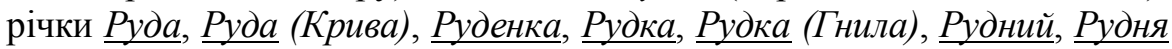

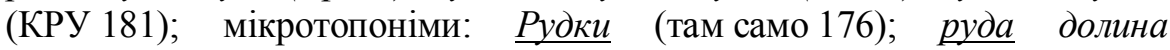
(Красний Брід 546); поодинокі назви сіл Рыжсики (1799-1801 ОЛУ 130); Puжки (XVIII там само 312); у пам'ятках із XVII ст. трапляється гідронім - озеро Рыжеватое Крывое.

Незначна кількість зафіксована давніх похідних: черезъ великое

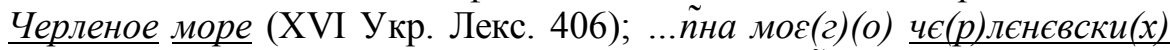
поби(л) и порани(л) (1609 ДМВН 126); ... п̈на мов(2)(о) места Чє(р)лєнов, побивши, порани(в)чи... (там само); Чعрлєнов місто $i$ масток Остафіяна Тишкевича (XVII там само 278); Черленків (1605 СелР 127); Черленівиі (1593 там само 399); чєрлєная доуброва (1495 ССУМ II 550); поодиноко номен виступає для найменування річки: Черлен, Черлена (КРУ 190).

На позначення червоного кольору вживався номен чирвоньй: где гора синай лежит и море чирвоне (XV Пов 16) та його синонімічний варіант черленый: которыи съ индеи и через море черленое ходлm (там само). У контексті пам'ятки вживається кілька варіантів на позначення червоного кольору, що є свідченням їхнього одночасного співіснування в XV ст.: и все же дно мор п червеного есть велми черлено. ижь дла чермности его вода албо вино на верхоу боцдоче боцдетсе видело червоно (там само 17).

-127- ㅇ. О. Іншакова, А. Є. Іншаков, 2017. 
Серед фактичного матеріалу наявні такі тематичні групи:

- географічні назви: Червона Русь - пізніша назва території Галииького князівства (XVII 30-і рр. ЛОстр 186); утопиль въ мори червономь (МатТимч II 478); містечко Червоне, Червоноградський повіт (1624 СелР 450); похідне старосты червонокградского (1641 ВУР І 329); потокъ Чирьвоныли... (1301 П 9); Червона Русь (СМШ II 403) «історична назва місцевості на сході від Карпат»; Червонка (КРУ 189);

- назви сіл похідні Багринівиі, Багриновичі (1646 СелР 482);

- назви річок Красна, Красний (КРУ 170);

- міста, містечка: Ржев, Ржищев, село Ржавец (ВУР I 560); Ржач, Ржавка, Ржавець (XVIII ОЛУ 312); Іржавський, Іржавець (там само 300); болото Ржаве, у пам'ятках із XVII ст. в системі

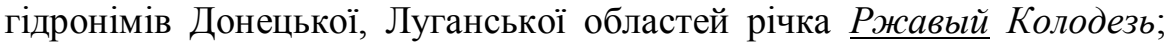
гідронім Ржавець.

У географічних та топографічних назвах функціонував кольорономен синій. У пам'ятках XV-XVII ст. як епітет моря використовується прикметник у складі власної назви. Синее море, мабуть, відносно до південних морів (Каспійського, Аральського): Синявин місто, Синяків село (УУГ 1040); Синято(в)ка село, маєтність (1611 АЖ 377); ...татарский полководеи, кочует на Синих Водах... (1648 ВУР II 47); село Синявское, містечка Синиць, Синява (1648-1654 там само III 625); Сиволж, Синеи - містечки, річка Синица, урочище Синица (там само I 560); Синие Bоды (там само II 542); того же року в Синяві татаре були з Волох... (XVII 30-і pp. ЛОстр 128); села Сингаївка, Синевідсько Нижнє, Синець, Синиия, Синівиі, Синявка, Синягівка, Синяківиі (XVII СелP 506-507); Сингаї село, масток (XVII ДМВН 277); Синечь, Синій Колодязь, Синьовка, Синьооківка, Синявка, Синяки (XVIII ОЛУ 314); село Синей Колодезь (1799-1800 там само 144); м tстечко Синявка (там само 138); село Синяки (там само 136); Синюха, Синявка, Синька (КРУ 182).

Географічні, топонімічні назви з номеном жовтий - переважно складені деривати: Жо(л)mїє Води (ЛГ 270) «урочище»; на ЖЖлтои

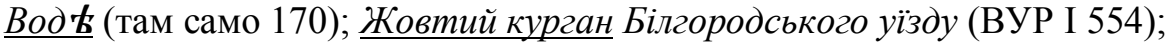
у урочища Жолтой Води (1648 ЛСам 49) «урочище»; Жовті Води (СМШ I 230) «назва річки»; балка Жовта круча; назви річок: Жовта, Жовтенька (КРУ 165).

Номен золотий міг виступати в складі композит або складених ㄷ І. О. Іншакова, А. Є. Іншаков, 2017. 
назв: місто Золотоноша (ЛГ 270); Золота Орда (XVIII ОЛУ 300); виявлено кілька похідних назв річок: Золотинка, Золотоношка, Золотий, Золота Липа (КРУ 166).

Зрідка номен сивий був твірною основою для географічних, топографічних назв: Сивки, Сиволож, Сивушанський, Сивиевий (XVIII ОЛУ 314).

Група назв зеленого кольору в староукраїнській мові $\epsilon$ розгалуженою мікросистемою. Дібраний матеріал дозволяє виокремити такі мікрогрупи:

- географічні назви: село Зеленів (1637 СелР 467); містечко Зелений Рiг (1645 там само 320); хуторь Зеленковскій (там само 167); хутор урочища Зеленаго (там само 176); гідронім Зеленыи Колодезь; Зеленківський (XVIII там само 300); топоніми Зеленча (Теребовельщина 179); річки Зелена, Зелениия (КРУ 166).

Отже, проаналізований матеріал засвідчує широке вживання кольоролексики в географічних та топографічних назвах протягом розглядуваного періоду. Деякі номени траплялися ще попереднього періоду. Найбільш продуктивними в опрацьованій тематичній групі стали білий, чорний, червоний кольори. Фактичний матеріал опрацьованих джерел дозволяє виокремити тематичні мікрогрупи: назви держав, міст, містечок, сіл, хуторів, слобід, повітів; гідронімічні найменування (морів, річок, озер); топонімічні назви (урочищ) тощо. Виявлений широкий спектр лексем із різними коренями для передачі червоного кольору. Менш продуктивними в аналізованій тематичній групі стали синій, жовтий, сивий, зелений кольори.

\section{Література}

1. Іншаков А. Історія кольоративів української мови : [монографія] / А. Іншаков ; за ред. проф. Ж. В. Колоїз. - Кривий Ріг : ФОП Маринченко С. В., 2017. - 211 с.

2. Муромцев I. В. Вибрані праці / I. В. Муромцев / Упорядкування і заг. редакція А. Нелюби. - Х. : Харківське історико-філологічне т-во, 2009. -312 с.

\section{Перелік умовних скорочень використаних джерел}

АЖ Акти Житомирського гродського уряду: 1590 р., 1635 р. Підгот. до вид. В. М. Мойсієнко. - Житомир, 2004. - 252 с.

ВолГр Волинські грамоти XVI ст. / Упор. В. Б. Задорожний, А. М. Матвієнко. Відп. ред. В. В. Німчук. - К. : Наук. думка, 1995. -246 с.

ВУР Воссоединение Украины с Россией : Документы и материалы (К 300-летию : 1654-1954) : в 3-х т. - М. : Изд-во АН СССР, 1954.

ГВК Купчинський О. Акти та документи Галицько-Волинського князівства XIII першої половини XIV століть. Дослідження. Тексти. - Львів, 2004. - 1284 с.

Гр Словарь української мови / Зібр. ред. журн. «Киевская старина». Упоряд., 3

-129- ㅇ. О. Іншакова, А. Є. Іншаков, 2017. 
дод. власн. матеріалу, Б. Грінченко. - К., 1907-1909. - Т. 1-4.

ДМВН Ділова мова Волині і Наддніпрянщини XVII ст. : зб. актових документів / Підгот. до вид. В. В. Німчук та ін. - К. : Наук. думка, 1981. - 316 с.

ДНМ Ділова і народно-розмовна мова XVIII ст. : матеріали сотенних канцелярій i ратуш Лівобереж. України / Підгот. В. А. Передрієнко. - К. : Наук. думка, 1976. - 416 с.

ЗЮРЗаписки о Южной Руси : Издал П. Кулиш. Т. 2. - К. : Дніпро, 1994. - 719 с.

IФ Першодрукар Іван Федоров та його послідовники на Україні / XVI - перша пол. XVII ст. / Зб. документів. Упор. Я. Д. Ісаєвич та О. А. Купчинський; О. Я. Мацюк, Е. Й. Ружицький. - К. : Наук. думка, 1975. - 344 с.

Кв.-Осн. Словник мови творів Г. Квітки-Основ'яненка : у 3-х т. - К. : ХДУ, 1978 1979. - T. 1-3.

КП Абрамович Д. Києво-Печерський патерик. Вступ. Текст. Примітки / Репринтне видання. - К. : Час, 1991. - 280 с.

КПС Книга Київського підкоморського суду (1584-1644); Відп. ред. В. В. Німчук. - К. : Наук. думка, 1991. - 344 с.

Красний Брід Горбач О. Південнолемківська говірка й діялекний словник c. Красний Брід бл. Меджилаборець / Пряшівщина // Олекса Горбач. Зібрані статті. V. Діялектологія. - Мюнхен : Український вільний ун-т, 1993. - С. 524-660.

КРУ Каталог річок України. Склали : Г. І. Швець, Н. І. Дрозд, С. П. Левченко. К. : Вид-во АН УРСР, 1957. - 192 с.

ЛГ Гисторія... Г. Граб'янки. Льтописъ краткій... / Упор. Мойсієнко В. М. Відп. ред. В. В. Німчук. - Житомир, 2001. -278 с.

ЛОстр Острозький літописець // Бевзо О. А. Львівський літопис і Острозький літописець. - К. : Наук. думка, 1971. - С. 125-140.

ЛСам Літопис Самовидця / Підгот. Я. І. Дзира. - К. : Наук. думка, 1971. - 208 с.

ЛьвЛ Львівський літопис // Бевзо О. А. Львівський літопис і Острозький літописець. - К. : Наук. думка, 1971. - С. 99-124.

МатТимч Тимченко Є. Матеріали до словника писемної та книжної української мови XV-XVIII ст. Упор. : Німчук В. В., Лиса Г. І. - Київ - Нью-Йорк, 2002. У 2-х книгах.

ОЛУ Описи Лівобережної України кінця XVIII - початку XIX ст. / Упор., передмова Т. Б. Ананієвої. - К. : Наук. думка, 1997. - 278 с.

П Грамоти XIV ст. / Упор., вступ. стаття, коментарі, словники-покажчики М. М. Пещак. - К. : Наук. думка, 1974. - 256 с.

Пов Перетц В. Н. Повесть о трёх королях-волхвах в западнорусском списке XV в. - Спб., 1903. - С. 1-107.

P В. Розов. Українські грамоти. T. I. XIV в. і перша пол. XV в. - К. : Друкарня Української Академії Наук, 1928. - 260, 83 с.

РД Русалка Дністрова (фотокопія 3 видання 1837 р.) / Вступ. стаття О. І. Білецького. - К. : Дніпро, 1972. - 135 с.

Романів Горбач О. Північно-наддніпрянська говірка й діалектний словник с. Романів Львівської області (відбитка з «Наукових записок» Українського Технічногосподарського інституту в Мюнхені. Т. VII (X), 1965 // Олекса Горбач. Зібрані статті V. Діалектологія. - Мюнхен, 1993. - С. 56-157.

СелР Селянський рух на Україні 1569-1648 рр. - К., 1993. - 532 с.

СМШ Словник мови Шевченка : у 2-х т. - К. : Наук. думка, 1964. - Т. 1-2.

ㅇ І. О. Іншакова, А. Є. Іншаков, 2017. 
ССУМ Словник староукраїнської мови XIV-XV ст. : у 2-х т. - К. : Наук. думка, 1977-1978. - Т. 1-2. - 591 с.

Теребовельщина Горбач О. Говірки Теребовельщини (відбиток 3 «Наукових записок» Українського Технічно-господарського інституту в Мюнхені, Т. XIX, Мюнхен, 1969) // Олекса Горбач. Зібрані статті. V. Діалектологія. - Мюнхен, 1993. - С. 173-257.

Укр. Лекс. Дэжё Л. Украинская лексика сер. XVI века : Няговские поучения (словарь и анализ). - Дебрецен, 1985. - 526 с.

УУГ Універсали українських гетьманів від Івана Виговського до Івана Самойловича (1657-1687). - К. - Л., 2004. - 1087 с.

Чаб Чабаненко В. А. Словник говірок Нижньої Наддніпрянщини. - Запоріжжя., 1992. Стаття надійшла до редакиї̈ 27.06.2017 p. 